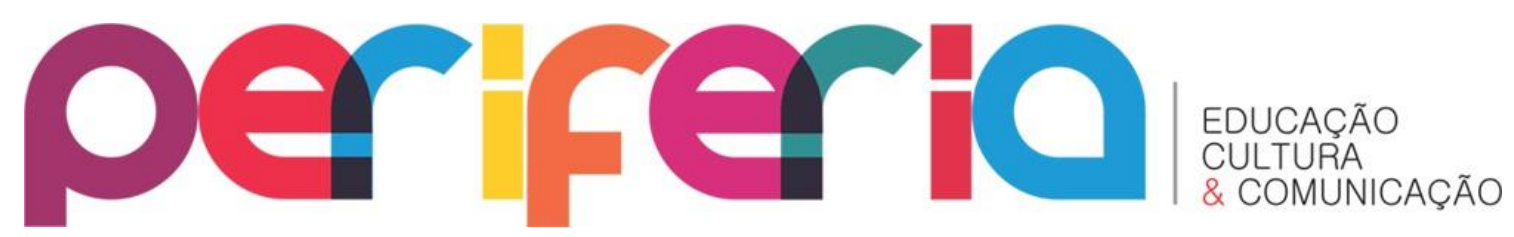

\title{
A ATUALIDADE DA LUTA DE CLASSES NA MODERNIDADE TARDIA
}

\author{
Elias Lopes de Lima ${ }^{1}$ \\ Universidade Federal de Juiz de Fora
}

\section{RESUMO}

Atualmente parece haver verdadeiro silêncio quanto ao problema da luta de classes na teoria social. Não por acaso. A despeito dos acirrados conflitos do operariado contra as forças hegemônicas do mercado, a classe operária ainda não correspondeu às expectativas revolucionárias que Ihe foram atribuídas. Não obstante, ao lado da classe operária uma série de grupos sociais e de organizações populares se mobiliza contra os mecanismos de exploração e contra os crescentes níveis de desigualdade característicos da sociedade capitalista. O presente artigo propõe uma releitura acerca da atualidade da luta de classes como sintoma da expansão das contradições do circuito de reprodução do capitalismo em escala global e a consequente emergência de um sem-número de grupos sociais, para além do proletariado, que reivindicam o estatuto de sujeito histórico a partir de suas ações reivindicativas e emancipatórias.

Palavras-chave: Luta de classes, classes sociais, capitalismo, sujeito histórico.

\section{CURRENT CLASS STRUGGLE IN LATE MODERN TIMES ABSTRACT}

Nowadays it seems that there is a true silence regarding the issue of class struggle in social theory. It is no accident. Despite the violent conflicts of the working class against hegemonic forces of the marketplace, the working class has not yet met the revolutionary expectations which have been assigned to it. Nevertheless, along with the working class, a number of social groups and popular organizations take action against the mechanism of exploitation and against the increasing level of inequality typical of the capitalist society. The current article suggests a rereading concerning the current class struggle as a symptom of the expansion of the contradictions of the reproduction circuit of capitalism in a global scale and the consequent emerging of an endless number of social groups beyond the proletariat which claim for the statute of the historical subject due to their demanding and emancipatory actions

Keywords: Class struggle, social classes, capitalism, historical subject.

\footnotetext{
${ }^{1}$ Doutor em Geografia pela Universidade Federal Fluminense. Professor do Programa de Pós-Graduação em Geografia e do Departamento de Geociências da Universidade Federal de Juiz de Fora. Pesquisador do Núcleo de Pesquisa Espaço e Ação - NuGea. E-mail: elias.lopes@ufjf.edu.br.
} 


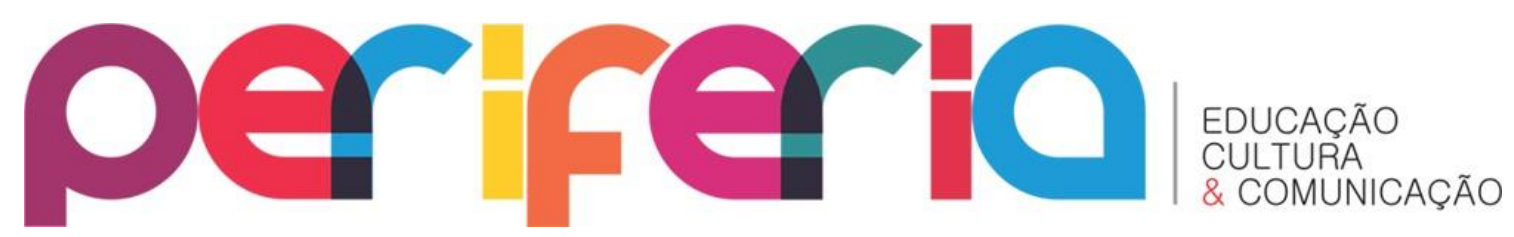

\section{INTRODUÇÃO}

Atualmente parece haver um verdadeiro silêncio quanto ao problema da luta de classes na teoria social. Não por acaso. A despeito dos acirrados conflitos do operariado contra as forças hegemônicas do mercado, a classe operária ainda não correspondeu às expectativas revolucionárias que historicamente lhe foram atribuídas. Aliás, não era essa classe que estava no centro dos principais movimentos revolucionários do século XX.

Apesar de algumas importantes conquistas que as organizações operárias viabilizaram (manutenção de emprego, aumento de salário, redução da jornada de trabalho etc.), o que se constata hoje em dia é que o proletariado parece, sob muitos aspectos, aparelhado pela ordem social vigente ${ }^{2}$, muito embora essa incorporação não tenha se dado de forma passiva. Variados são os nódulos de força decorrentes desse ajustamento, pelo que se evidencia a formação de um movimento contracultural com ramificações em todas as esferas de sociabilidade, o que acarretaria, porém, a criação de partidos políticos operários comprometidos mais com reformas institucionais do que com transformações sociais de monta (HOBSBAWM, 2000, p. 390) ${ }^{3}$.

Não obstante, um número cada vez maior de pessoas em todo o planeta passou a desempenhar, a partir da ampliação do arco de exploração do capitalismo à escala global, algum papel na vida econômica e política da sociedade e do processo de produção em geral, mesmo que o seja a título de reserva (de recursos, de mão de obra, de consumo etc.). Em decorrência, um enorme contingente de indivíduos, grupos

\footnotetext{
2 "Há muitas questões, incluindo impostos, tarifas, subsídios e políticas de regulação tanto internas quanto externas, em que o capital industrial e o trabalho organizado em determinados contextos geográficos será um aliado em vez de opositor. Isso ocorreu com o pedido de socorro da indústria automobilística dos EUA em 2008 e 2009. As montadoras e os sindicatos sentaram lado a lado na tentativa de preservar os empregos e salvar as empresas da falência" (HARVEY, 2011, p. 53-54).

3 Mattos (2007, p. 51) observa ainda que "o reerguimento eleitoral dos partidos socialdemocratas/trabalhistas, bem como de suas agremiações partidárias originadas dos antigos partidos comunistas, deu-se às custas de sua completa domesticação pelos princípios neoliberais ('não há alternativa', repete o coro)".
} 


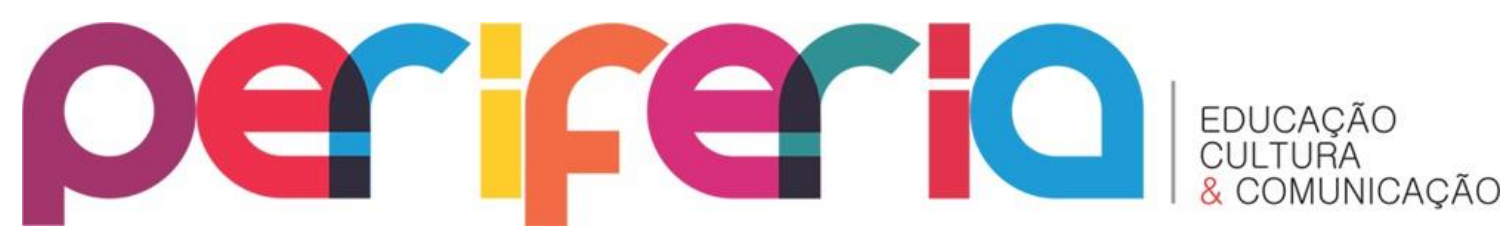

sociais e organizações populares se soma à luta contra os mecanismos de exploração e contra os altíssimos níveis de desigualdade característicos do capitalismo.

O presente artigo propõe uma releitura acerca da atualidade da luta de classes como sintoma da expansão das contradições do circuito de reprodução do capitalismo em escala global e a consequente emergência de um sem-número de grupos sociais, para além do proletariado, que reivindicam o estatuto de sujeito histórico a partir de suas ações reivindicativas e emancipatórias.

\section{A ABJUDICAÇÃO DA CONSCIÊNCIA DE CLASSE}

Abordar questões relativas às classes sociais tem se tornado um verdadeiro tabu nas ciências em geral, causando espécie entre os núcleos mais conservadores e, não raro, a sensação de que se trata de um tema antiquado, em todo caso, enfadonho e dado por superado até mesmo por alguns intelectuais de esquerda. "Como a tosca noção de classe atribuída a Marx pode ser criticada sem dificuldades, assume-se que qualquer noção de classe é uma construção teórica pejorativa, imposta às evidências. Nega-se absolutamente a existência da classe", constata Thompson (2010, p. 10-11).

A mera adjetivação de algumas expressões correntes associadas à noção de classe, como, por exemplo, "pensamento burguês", "organização proletária", "sociedade burguesa", "movimento operário", causa desde logo ligeiro desconforto, se não algum juízo de valor. Não é difícil preferir expressões mais "atualizadas" ou "adequadas" como "pensamento hegemônico", "organização da força de trabalho",

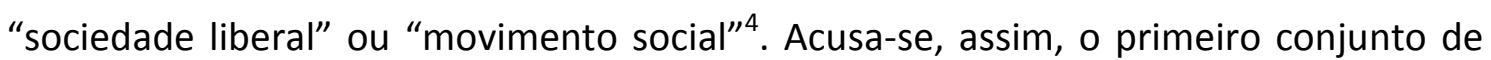
expressões de ser demasiado impreciso para ser útil como análise séria em favor de outras expressões supostamente mais apropriadas, todavia, sujeitas às mesmas objeções ou até menos precisas. "Talvez seja interessante observar que, enquanto o

\footnotetext{
${ }^{4}$ É claro que a noção de movimento social é bem mais ampla que a de movimento operário, este mesmo podendo ser considerado um movimento social. Assim confirma Lojkine (1997, p. 291), para quem os movimentos sociais correspondem ao "mais alto grau de expressão da luta de classes". Mas não se pode negar que a predileção pelo conceito de movimento social vem a reboque da ampliação das contradições do capitalismo sem que essa expansão tenha sido acompanhada pela devida atualização da teoria da luta de classes, que ficou restrita ao revisionismo perpetrado pelo marxismo cientificista eurocomunista.
} 


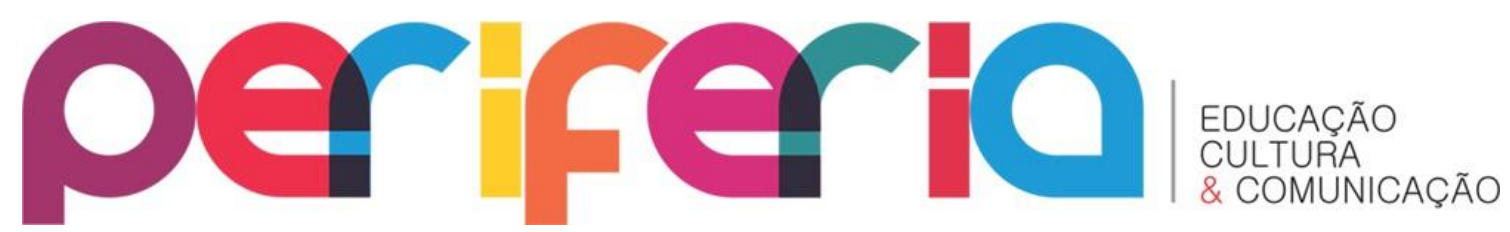

primeiro conjunto de termos chama a atenção para o conflito ou tensão dentro do processo social, o segundo parece cutucar-nos para que vejamos a sociedade em termos de uma ordem sociológica autorreguladora", auxilia-nos Thompson (1998, p. 27) a descortinar esse véu ideológico.

Nenhuma categoria histórica foi mais incompreendida, atormentada, transfixada e des-historizada do que a categoria de classe social; uma formação histórica autodefinidora, que homens e mulheres elaboram a partir de sua própria experiência de luta, foi reduzida a uma categoria estática ou a um efeito de uma estrutura ulterior, das quais os homens não são os autores mas os vetores (Idem, 1981, p. 57).

No dia a dia, é comum não identificarmos um operário por sua condição de classe, senão como empregado deste ou daquele segmento econômico. Aliás, uma breve consulta ao dicionário revela que o verbete "operário" não está associado a qualquer referência que sugira a ideia de classe. Quando muito, admite-se entre os núcleos conservadores uma distinção econômica meramente formal e quantitativa, sem qualquer conteúdo histórico, entre classe baixa, média e alta (ou $A, B, C$ ) e as não menos estáticas gradações entre cada uma delas, muito embora sugiram uma (enganosa) mobilidade social. $\mathrm{O}$ fato de a economia política se referir a um estrato não muito preciso da burguesia como classe média de certo modo sancionou essa estratificação. Admite-se, então, a ideia de classes não por razões culturais, políticas e históricas, mas pelo fato de que os indivíduos que as compõem teriam a suposta possibilidade de ascender à classe imediatamente superior, galgando uma ascensão vertical a depender, é claro, de sua "livre iniciativa" e "espírito empreendedor" - para todos os fins, excluindo qualquer possibilidade de transformação social.

A rigor, as objeções em relação às questões atinentes às classes sociais parecem menos voltadas para algumas classes do que em especial para a burguesia e para o proletariado. As questões relativas ao clero, à nobreza ou ao campesinato, por exemplo, não suscitam, via de regra, tal embaraço, em que pese ainda o fato de alguns desses estratos, sobretudo os mais populares (ainda que organizados) não serem considerados pela historiografia oficial sujeitos históricos portadores de um projeto de emancipação e de transformações sociais de efeito. 


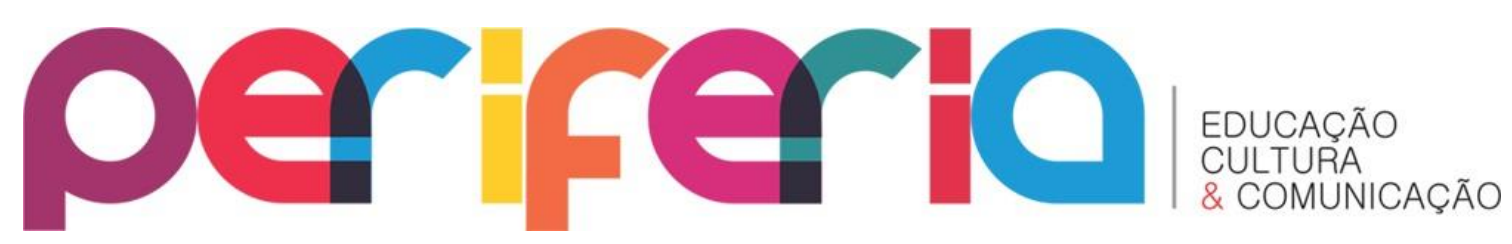

Embora o campesinato, dentre outros grupos sociais, tenha se organizado e demonstrado por diversas vezes seu descontentamento em ações reivindicativas por reforma agrária, a abjudicação da consciência ${ }^{5}$ segundo um ideal burguês de mundo não possibilita identificar tais agitações como concernentes à luta de classes, senão como distúrbios à ordem pública e à apropriação indébita da propriedade privada. Não por incapacidade de discernimento, obviamente, mas antes por uma disposição deliberada para dissimular qualquer conotação alusiva aos conflitos entre classes.

É nesse mesmo espírito que um conservador indisfarçável como François Furet (1989) tenta, a todo custo, desviar qualquer alusão ao conflito de classe entre a burguesia e o "povo" para um conflito entre esse último e a aristocracia, por ocasião de sua análise da Revolução Francesa. Para garantir seu intento, ele lança mão de uma nomenclatura inequívoca: "povo", como se sabe, não é classe. Menos suspeito de partilhar desse desdém para com as classes, o historiador marxista Georges Lefebvre $\left(1989\right.$, p. 44) não considera o clero uma classe social ${ }^{6}$. Talvez seja sensato supor que essas classes prescreveram o seu "tempo histórico", para utilizar uma expressão recorrente no próprio vocabulário marxista. Não exatamente por não serem mais classes, como recomenda Lefebvre em relação ao clero, mas sim pelo fato de que não estariam supostamente entrincheiradas no front da luta de classes, isto é, radicadas em nossa consciência como uma possível ameaça ao establishment.

Quijano (2010, p. 99-100) explica que o conceito de classe social entra em desuso com a dissolução dos regimes socialistas a partir da década de 1980, retornando à cena política mundial com a crise da hegemonia global do capitalismo financeiro e do atual desprestígio do neoliberalismo. Esse mesmo autor, a despeito de suas posições críticas à sociedade capitalista, considera que a noção de classe social se tornou reducionista e a-histórica (p. 117).

\footnotetext{
${ }^{5}$ A abjudicação da consciência de classe é uma expressão utilizada por Lukács (2003) para aludir à maneira como as classes sociais, em especial o proletariado, assimilam (não sem algumas contradições no plano prático) os valores, os símbolos, as referências teórico-conceituais e o ser social concernentes à visão de mundo da burguesia e, portanto, da sociedade capitalista.

${ }^{6}$ "O clero na verdade é uma profissão e não uma classe social" (ibid.). O historiador registra, inclusive, que bispos, abades e cônegos integravam a nobreza, sendo senhores em inúmeras aldeias no final do século XVIII.
} 


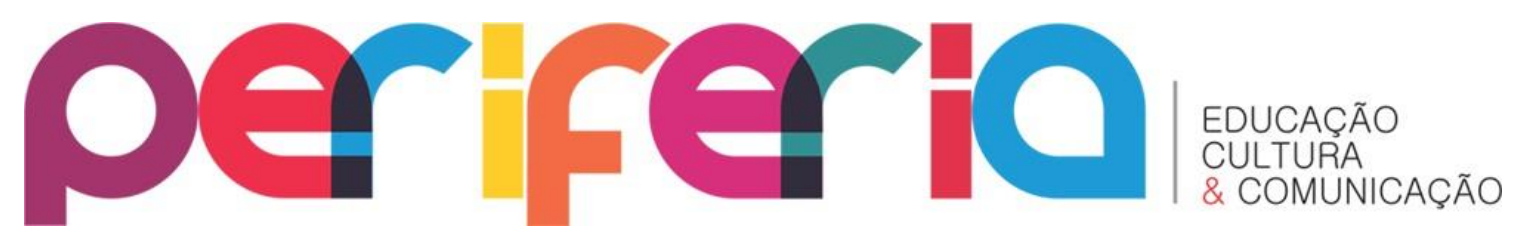

O não reconhecimento das classes sociais e de suas lutas como autorreferência para os grupos humanos ou, quando muito, a sua admissão em uma escala muito limitada e secundária estariam associados, de acordo com Mattos (2007, p. 48), à perda da centralidade da categoria trabalho nas ciências sociais. Presumivelmente, o teor metadiscursivo e cientificista de alguns aportes conceituais da teoria marxista parece ser um motivo mais que suficiente para que qualquer alusão à luta de classes seja descartada por muitos analistas. Embora agregue a mais radical crítica à sociedade capitalista, o marxismo não deixa de realçar uma recorrente metanarrativa que faz da contradição capital-trabalho um dado objetivo universal, inscrevendo-se, portanto, tanto quanto algumas correntes da tradição racionalista e positivista, em um domínio ideológico abjudicador da consciência.

A teoria marxista não deixa de sorver alguns dos princípios fundamentais que consolidaram a ordem burguesa, partilhando a visão otimista e secular de liberdade e de progresso - verdadeiros libelos do pensamento burguês-iluminista ${ }^{7}$. Assim, ela prescreve que a sociedade humana e o indivíduo estão predestinados a um aperfeiçoamento no curso da história com base na ciência, na técnica e na razão, admitindo, com isso, uma versão triunfalista da conquista da natureza pelo homem. Ela também é herdeira de um conjunto de aspirações e de atitudes morais derivado das experiências revolucionárias impetradas pela burguesia na passagem do século XVIII para o XIX. Por fim, o marxismo parece privilegiar, como sujeito histórico, as classes burguesa e proletária, não contemplando outros grupos sociais como agentes de transformação, derivando dessa restrição, com toda justiça, a relevância da crítica ao seu teor eurocêntrico.

Em geral, os movimentos trabalhistas e emancipatórios convivem com uma contradição intestina, pois jamais foram capazes de propor um corpo epistemológico efetivamente independente da matriz de racionalidade hegemônica. Seu corpo organizacional encontra-se deveras fragmentado e os interesses são os mais

\footnotetext{
${ }^{7}$ Thompson (1981, p. 187) confirma que "Marx partilha com outros grandes e fecundos pensadores (Hobbes, Maquiavel, Milton, Pascal, Vico, Rousseau) uma ambiguidade inerente ao rigor mesmo e à abertura de seu pensamento".
} 


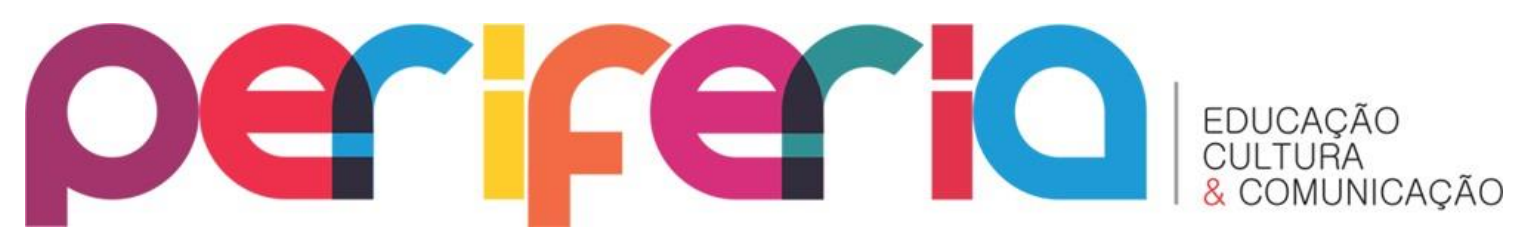

controversos, se avaliarmos menos do ponto de vista da unidade de classe do que da estratificação corporativista, característica das organizações operárias. Isso dificulta até mesmo especular, nas atuais circunstâncias, sobre sua consciência de classe em uma perspectiva que não seja de caráter teórico.

Conquanto a classe trabalhadora almeje por transformações sociais, ainda que por meio de reformas, não há um projeto político sólido e autônomo que suscite mudanças estruturais efetivas em bases teórico-conceituais próprias por parte dos movimentos sociais trabalhistas. Mesmo as correntes socialistas, que se supõe terem avançado mais nesse sentido, são em última análise tributárias dos ideais universalistas erigidos por alguns baluartes do pensamento conservador (Kant, Spinoza, Leibniz, Hegel e outros). Um socialista poderia discordar em praticamente tudo de um capitalista, menos das verdades e das leis seculares que regem o universo: a liberdade, o progresso, a razão e a humanidade, dentre alguns outros ideologemas ${ }^{8}$.

A propósito, uma questão polêmica é que a teoria marxista, na condição de derivação do próprio horizonte objetivo burguês (embora se mantivesse crítica e recalcitrante a muitos de seus postulados), seria equivocadamente interpretada como "pensamento proletário". Mas não há propriamente um "pensamento proletário", se por essa expressão alude-se a uma oposição ao corpo de doutrinas teóricometodológicas construído historicamente pelo "pensamento burguês", senão um modo de pensar que se traduz muito mais por meio de expedientes práticos do que por uma atividade contemplativa.

Pode-se até admitir que haja um "pensamento revolucionário", mas não exatamente proletário, no sentido de um conjunto sistemático de ideias derivadas da consciência de classe do operariado. Porquanto essa consciência está atrelada, por diversos liames, à consciência de classe burguesa: seja pela imbricação que ambas mantêm com o ser social como produto e, ao mesmo tempo, condição das relações capitalistas de produção; seja pela assimilação dos ideologemas seculares e

\footnotetext{
${ }^{8}$ Ideologema designa termos, expressões ou conceitos que induzem a uma determinada ideologia dominante.
} 


\section{periferio}

universalistas proclamados pela burguesia quando esta se estabeleceu como classe hegemônica.

\section{A CORPORIFICAÇÃO DA CONSCIÊNCIA DE CLASSE TRABALHADORA}

O princípio ontológico que rege as representações de mundo da burguesia é o mesmo princípio ontológico que atua na concepção de mundo do proletariado, de modo que o ser social da sociedade capitalista, isto é, as determinações históricoexistenciais dessa sociedade, é compartilhado por ambas as classes ${ }^{9}$. Com base em uma implicação dialética, os valores e as representações da burguesia se assentam em um ser social historicamente determinado, sendo esses mesmos valores, portanto, produtos de determinações históricas.

Por correspondência ao ser social, as representações e a própria consciência de classe do operariado estariam igualmente subjacentes aos valores e às representações da burguesia. Endossando essa assertiva, Marx e Engels (2005 [1848], p. 57) escrevem no Manifesto comunista que "as idéias [sic] dominantes de uma época sempre foram as idéias [sic] da classe dominante". Logo, se não há propriamente uma consciência de classe por correspondência a um ser social próprio e autônomo, que não seja o mesmo ser social aventado pela burguesia, é pouco provável que se reúnam as condições efetivas para a elaboração de uma teoria proletária igualmente autônoma.

É claro que essas determinações não são tão rígidas e arbitrárias a ponto de não haver divergências entre as representações da classe burguesa e as da classe trabalhadora. Embora Lukács (2003, p. 310) reconheça a concordância ontológica entre as duas classes, também ressalta que suas categorias interpretativas podem ser fundamentalmente específicas em "consequência da diversidade de situação das duas classes no 'mesmo' processo econômico".

\footnotetext{
${ }^{9}$ Thompson (2010, p. 10) explica que "não podemos ter duas classes distintas, cada qual com um ser independente, colocando-as a seguir em relação recíproca". Na mesma linha, Lukács (2003, p. 310) concorda que "a realidade objetiva do ser social é, em seu imediatismo, 'a mesma' para o proletariado e para a burguesia".
} 


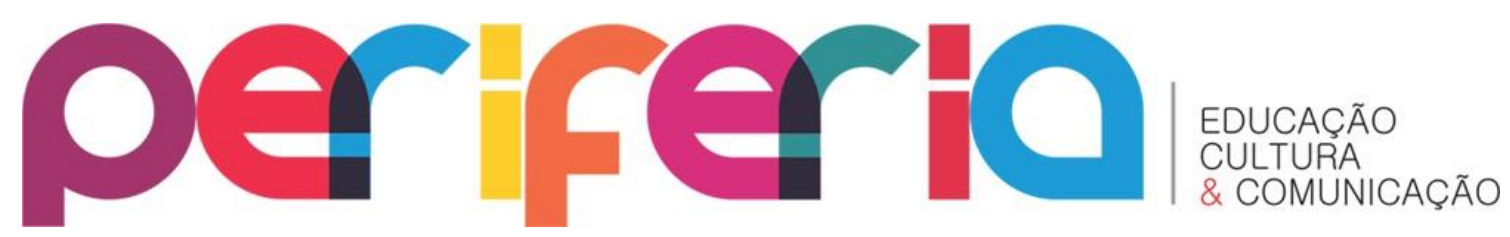

Assim, a concepção de mundo da classe trabalhadora seria, em tese, uma espécie de híbrido de valores e de representações com base em sua própria experiência reprodutiva. Mas essa possibilidade é constantemente suprimida pelo controle, exercido pela burguesia, do aparato de difusão ideológica (que inclui a produção do conhecimento, aparelhos normativos, propagação de uma cultura de massa etc.) e da consequente reificação de determinados conteúdos objetivos.

Não obstante, a objetivação do real por parte da classe trabalhadora passa menos pela subsunção de categorias, no sentido rigoroso do termo, do que pela corporeidade, considerando que é mobilizada pela atividade prática vital do trabalho. Mas aqui também o trabalho livre e alienado cumpre o seu papel na abjudicação da consciência do trabalhador.

Expondo as contradições da sociedade capitalista, o marxismo não pôde evitar muitas das contradições em que se enredou posteriormente, e talvez seja exatamente essa vacância a força de sua coerência crítica. Mas considerá-lo uma filosofia da história determinante da "missão" revolucionária do proletariado, se por isso depreende-se um contraponto ao pensamento liberal-burguês, só contribui para desviar cada vez mais do problema da luta de classes ${ }^{10}$. De outro modo, são as condições históricas atinentes ao desenvolvimento das forças produtivas, e não prognósticos teóricos de quem quer que seja, que autorizariam ou não uma transformação social e mesmo o estabelecimento de outro modelo de sociedade. A propósito, Thompson (1981, p. 190) reconhece que "o projeto do Socialismo não está garantido por nada - certamente não pela 'Ciência' ou pelo marxismo". Um pensamento genuinamente proletário deveria contemplar, como não deixam de sublinhar alguns marxistas conscientes desses imbróglios, o horizonte objetivo reificado face ao imperativo da propriedade privada e da abjudicação da consciência mediante a influência do ideal burguês de mundo, porém menos por sua anuência teórica do que por sua coerência prática e sensível.

\footnotetext{
${ }^{10}$ Bensaïd (2006, p. 237) concorda que o "obscurecimento da luta de classes é propício para as seduções do mercado e para a escalada de conflitos localistas".
} 


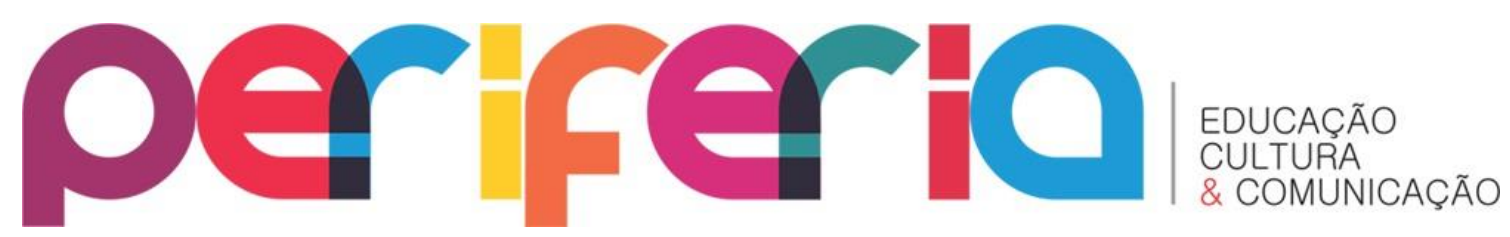

A luta de classes deve ser compreendida, nesse caso, em sua vinculação com a práxis, isto é, a partir da apreensão objetiva pela consciência subjacente à atividade prática transformadora das condições materiais de existência. Não por acaso, Lefebvre (2006, p. 44) admite o trabalho, categoria ontológica segundo a qual as classes (sobretudo a trabalhadora) estariam umbilicalmente associadas, mais como uma prática concreta ou uma realidade em seu devenir do que um conceito que traz consigo um antagonismo (o capital). Sendo assim, deveríamos reconhecer as classes sociais menos como uma "categoria" teórica do que como um fenômeno histórico, uma evidência real que pode ser demonstrada nas relações humanas, as quais convocam outros sujeitos históricos a protagonizar a história (THOMPSON, 2010, p. 9) ${ }^{11}$.

Estamos falando de homens e mulheres, em sua vida material, em suas relações determinadas, em sua experiência dessas relações e em sua autoconsciência dessa experiência. Por 'relações determinadas' indicamos relações estruturadas em termos de classes, dentro de formações sociais particulares (1981, p. 111).

A problematização das classes e, principalmente, da luta de classes não consiste, portanto, em reclamar um corpo doutrinário de conceitos e de categorias alçadas ao plano das generalidades, mas sim em realçá-las como implicação prática da experiência humana. As classes surgem, argumenta Thompson (1981, p. 121), "porque homens e mulheres, em relações produtivas determinadas, identificam seus interesses antagônicos e passam a lutar, a pensar e a valorar em termos de classe: assim o processo de formação de classe é um processo de autoconfecção". Elas se estruturam a partir das experiências de indivíduos de carne e osso, de sujeitos corporificados: derivam das vicissitudes da divisão social do trabalho, da precarização das condições de existência e da constatação dos mecanismos de exploração a que estão submetidos.

\footnotetext{
11 “Toda essa 'merda' (Geschichtenscheissenschlopff) na qual tanto a sociologia burguesa como o estruturalismo marxista estão mergulhados até o pescoço (Dahrendorf ao lado de Poulantzas, a teoria da modernização ao lado da prática teórica), nos foi cagada pela paralisia conceptual, pela deshistorização do processo e pela redução da classe, ideologia, formações sociais e quase todo o resto à estase categórica" (p. 122).
} 


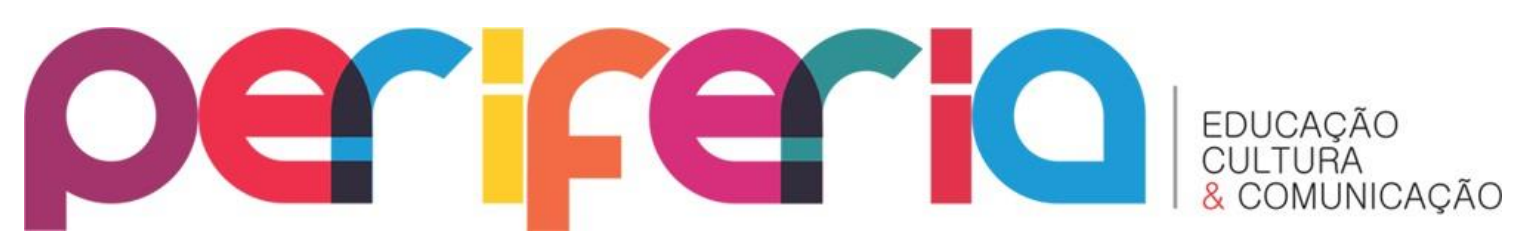

A consciência da classe trabalhadora consiste, assim, muito mais em uma consciência corporificada, cuja orientação objetiva deriva da práxis e da experiência, do que exatamente de um conjunto de doutrinas analíticas e contemplativas. Queremos dizer, em outras palavras, que o corpo, como sede de toda práxis humana, é o domínio ontológico mediador entre a teoria e a prática, entre a consciência social e o ser social. O que Thompson $(1998,2010)$ qualifica como "experiência" em sua disposição em rediscutir, em outras bases de inteligibilidade, as classes sociais, para nós comparece como experiência de corporeidade, fundamento ontológico das classes e dos mais variados modos de existência na qualidade de sujeitos históricos concretos. Logo, nada mais pertinente do que qualificar esses coletivos sociais como sujeitos corporificados. A eloquente admissão das classes sociais como o "corpo" da luta de classes $^{12}$ pelo historiador inglês é, para nós, uma implicação real que se expressa em sua prática laborativa, em sua forma peculiar de objetivação dos conteúdos do real e em suas estratégias reivindicativas e emancipatórias.

Convém admitir, contudo, que a hipostasiação da classe social a um preceito universalista foi, em grande parte, gerada muito mais pela ortodoxia dos epígonos, que procuraram de todas as maneiras realçar o teor cientificista do marxismo, do que pelo próprio $\mathrm{Marx}^{13}$, embora não se possa eximi-lo de ter incorrido, vez por outra, no cientificismo. Essa preocupação é explícita em Engels. No final de sua vida, ele parece decidido a destacar o caráter cientificista de $O$ Capital e de algumas outras obras de Marx. No prefácio da terceira edição d'O 18 de Brumário de Luís Bonaparte, Engels (2010, p. 22) compararia o que considera uma "lei da luta de classes à lei da transformação da energia nas ciências naturais". O que Lênin, Plekhanov, Kautsky e, mais tarde, Althusser ${ }^{14}$, dentre tantos outros, fizeram foi aprofundar ainda mais o teor

\footnotetext{
12 "Mas a luta de classes é o processo (ou uma parte dele) e as classes em luta são o corpo (ou uma parte dele)" (idem, 1981, p. 123).

13 "Quando Marx disse a Engels, ao que parece um par de vezes, entre 1880 e 1881, já na sua velhice, 'eu não sou marxista', estava protestando contra a leitura e o aproveitamento que naquela época faziam de sua obra econômica e política, pessoas (...) que interpretavam mecanicamente 0 capital", observa Buey (2004, p. 23).

${ }^{14}$ Este, inclusive, é ainda mais eloquente em sua tese da história como um "processo sem sujeito" (THOMPSON, 1981, p. 131), assumindo a fórmula de "base" e "superestrutura" que atribui, por fim, ao
} 


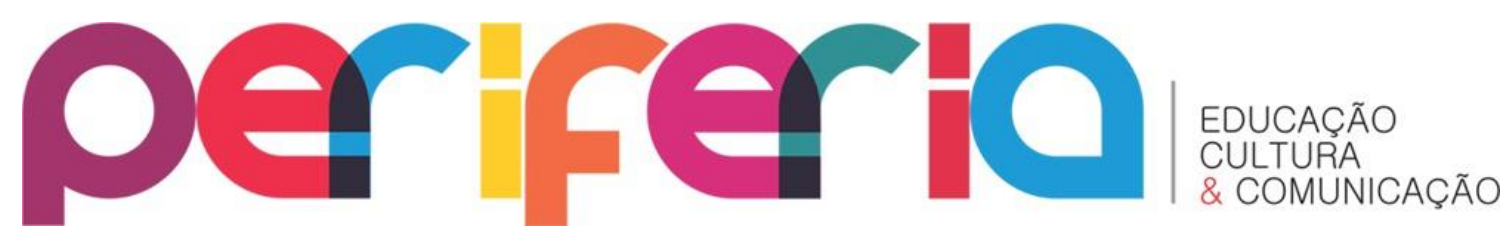

cientificista encetado por Engels e até mesmo por Marx em suas obras de maturidade ${ }^{15}$. A orientação cientificista da teoria da luta de classes, somente esboçada por Marx a partir dos textos de Saint-Simon e outros socialistas utópicos, tem acarretado hoje, quando todo tipo de objetivismo passa a ser rechaçado em meio à crise do conhecimento moderno, uma antipatia nada velada contra qualquer tentativa de revitalizá-la ${ }^{16}$, para não mencionar novamente os ideologemas conservadores que nutrem essa indisposição.

\section{A EMERGÊNCIA DOS NOVOS (OUTROS) SUJEITOS HISTÓRICOS}

Uma vez adornado pelo cientificismo marxista, o proletariado é alçado ao status de sujeito histórico por excelência, sendo todas as outras classes ou grupos sociais convertidos em meros objetos do conhecimento. No limite, esses coletivos seriam considerados sujeitos a-históricos incapazes de produzir, por si mesmos, um conhecimento válido e, principalmente, de mobilizar recursos suficientes para transformações sociais. Abrindo mão da experiência sensivel e prática dos sujeitos, os epígonos não compreenderam a própria classe trabalhadora como sujeito histórico corporificado, senão como um princípio analítico universalista.

É nesse mesmo espírito que o jovem Lukács (2003) é conduzido a considerar o proletariado como o "sujeito-objeto idêntico" da história, embora o mesmo não lançasse mão de uma atitude cientificista, senão de elementos da filosofia, o que o tornou alvo de críticas por parte dos epígonos, que qualificariam sua contribuição como um revisionismo.

Estado (como personificação do partido) o papel de agente histórico, limitando as classes e indivíduos a meras figuras decorativas subordinadas às determinações estruturais.

${ }^{15}$ Thompson (p. 186) observa que "é na noção mesma do marxismo como 'Ciência' que encontramos a marca registrada do obscurantismo, e de um obscurantismo copiado, como tantas outras coisas, de uma ideologia burguesa de grande longevidade". Devemos supor que o grifo do sufixo "ismo" não é casual. "O marxismo também se propôs, com frequência, a 'abstrair dos sentimentos do homem as suas esperanças' e fixá-las no elemento mais puro da 'ciência'” (p. 200).

${ }^{16}$ É claro que esse problema se deve também aos aspectos políticos que envolveram a dissolução do regime socialista na Europa, a consequente difusão do neoliberalismo como corrente político-ideológica dominante até o final do século XX e início do XXI e a crescente refutação pós-moderna e culturalista de axiomas estruturais e metanarrativas. 


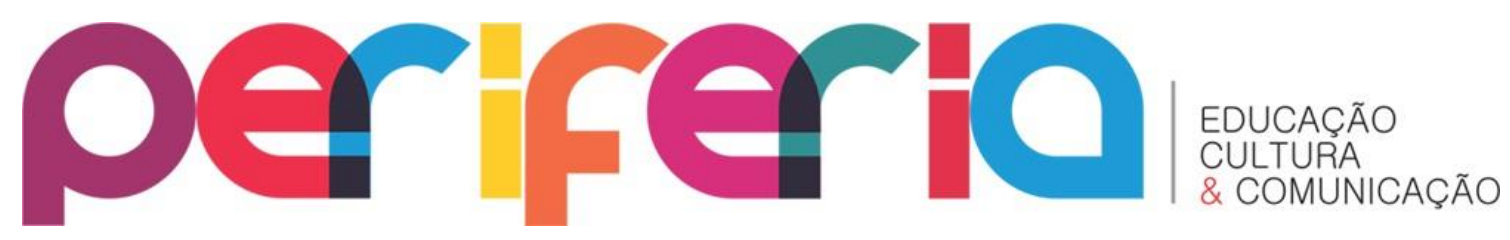

Lukács insistiu na argumentação de que somente as classes com potencialidades de atingir uma totalidade histórica, isto é, de esgotar a essência objetiva da sociedade capitalista seriam dignas de serem reconhecidas como sujeitos históricos. As classes que, segundo o filósofo húngaro, estariam supostamente aptas a tanto seriam a burguesia e, em especial, o proletariado, porquanto também seriam elas as únicas implicadas, efetivamente, nos mecanismos de produção e de exploração do capitalismo. Logo, como que em resposta à sua proposição inicial, seriam as únicas a deter uma consciência da totalidade histórica da sociedade capitalista. De acordo com Lukács (2003, p. 144),

[...] toda classe cuja consciência não disser respeito à totalidade da sociedade, então essa classe só poderá desempenhar um papel subordinado e nunca poderá intervir na marcha da história como fator de conservação ou de progresso. Tais classes estão em geral predestinadas à passividade, a uma oscilação inconsequente entre as classes dominantes e as revolucionárias, e suas explosões eventuais revestem-se necessariamente de um caráter elementar, vazio e sem finalidade e, mesmo em caso de vitória acidental, estão condenadas a uma derrota final.

Entretanto, a burguesia encontra-se impedida de alcançar a totalidade social em razão de seus interesses egoístas, o que leva Lukács a concluir que o proletariado seria o único sujeito histórico com condições reais para tanto, mesmo que não seja capaz de fazê-lo de modo consciente na atual conjuntura histórica. Essa hipótese se assenta na divergência de determinados interesses de classes historicamente determinados, isto é, com base no ser social.

Para a burguesia, o ser social permanece irresolutamente preso a um corpo doutrinário de representações que o qualifica como um ser estático e naturalizado. Com isso, essa classe visa, de maneira consciente ou inconsciente, coibir qualquer contradição que ponha em risco suas prerrogativas em uma sociedade profundamente desigual.

Para a classe trabalhadora (para além do proletariado), o mesmo ser social tende a ser transcendido, considerando que as contradições sociais convergem para o próprio corpo dos indivíduos, sede de sua atividade prática vital. A exemplo da 


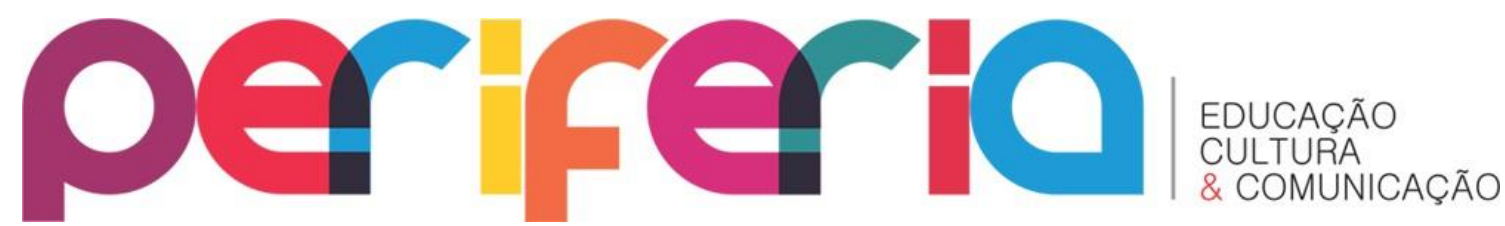

burguesia, o incremento progressivo do conhecimento da realidade pela classe operária conduziria à sua aniquilação, muito embora essa dispersão se traduzisse para os indivíduos que a compõem em emancipação.

O filósofo húngaro formulou essas ideias nos anos 1920, no auge da fase industrial do capitalismo (véspera da eclosão da crise de superprodução de 1929), envolvido ainda no que ele próprio qualificou, mais tarde (no prefácio de 1967 de História e consciência de classe), como um "utopismo messiânico" característico do clima ideológico gerado pela Revolução de 1917. Não the ocorreu, então, que o capitalismo poderia estender seus tentáculos a todos os recônditos e grupos sociais sobre a face da Terra, muito embora Marx e Engels (2005, p. 45) tivessem advertido sobre essa difusão planetária do capitalismo no Manifesto comunista, aludindo inclusive à "destruição das forças produtivas" e à incorporação de "novos mercados"17. Mas convenhamos que o efeito de um prognóstico sobre nossa representação de mundo não se compara ao efeito de uma evidência real.

Se em dado momento histórico a impossibilidade de se constituir como sujeito histórico poderia ser atribuída aos estratos sociais que supostamente não possuíam consciência de classe por não estarem diretamente implicados na reprodução do capitalismo, como era aparentemente o caso das populações camponesas e outros gêneros de vida de regime comunitário, atualmente não parece ser mais assim.

A ampliação da escala de exploração do capitalismo, incorporando, em uma divisão geográfica do trabalho ${ }^{18}$, tanto os mais diversos grupos sociais (não necessariamente proletários) quanto seus espaços de vivência, parece ter-lhes incutido uma consciência objetiva histórica. Não por acaso, esses agentes passaram a compor

\footnotetext{
17 "O sistema burguês se tornou demasiado estreito para conter as riquezas criadas em seu seio. E de que maneira consegue a burguesia vencer essas crises? De um lado, pela destruição violenta de grande parte de forças produtivas; de outro, pela conquista de novos mercados e pela exploração mais intensa dos antigos" (ibid.). Wallerstein $(2001$, p. 22, 26) interpretaria essa "destruição da força produtiva" como um processo de desproletarização.

${ }^{18}$ Designamos como divisão geográfica do trabalho o plano conceitual que envolve ao mesmo tempo múltiplas dimensões e escalas da divisão do trabalho (social, territorial, regional, internacional etc.), já que o sentido de geográfico implica múltiplas escalas e variáveis.
} 


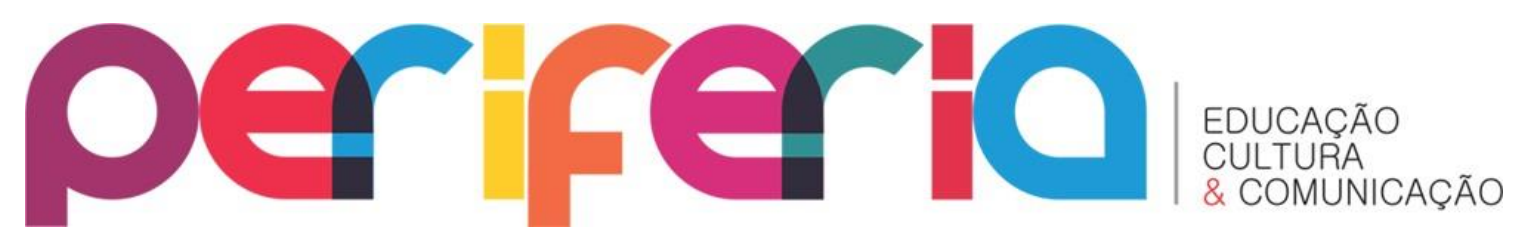

uma agenda de ações contra-hegemônicas de subversão ao mercado e aos valores culturais da sociedade capitalista.

Nesse caso, o recrudescimento das mais variadas manifestações contra as forças capitalistas por parte de iniciativas populares e de movimentos sociais formados por estratos sociais historicamente negligenciados pela economia política marxista, sobretudo em sua ortodoxia cientificista, pode perfeitamente ser considerado atualização de questões concernentes à luta de classes.

Ainda que reticentes a outras classes ou grupos sociais, as questões colocadas por Lukács formatam a base para a emergência e a atualidade de outros sujeitos históricos além da burguesia e do proletariado. Não se trata, portanto, de reconhecer a classe operária como o único sujeito histórico, muito menos como o sujeito histórico "privilegiado" da luta de emancipação da humanidade, como supõe Houtart (2006, p. 422). Interessa-nos aproveitar o importante approach da ontologia da práxis aventada por Lukács e Marx, desdobrando algumas considerações seminais acerca do papel histórico da classe trabalhadora, de maneira a estender esse aporte teórico a outros estratos sociais que não somente as classes privilegiadas como sujeitos históricos pela economia política.

O operariado e tantos outros grupos sociais que passam a engrossar o contingente de força de trabalho explorada pelo capitalismo seriam, em tese, perfeitamente capazes de empreender uma mediação objetiva da totalidade em razão das contradições a que são submetidos via conversão de sua força de trabalho (seu corpo) - seu "único" e legítimo meio de produção - em um objeto alienável.

Somente a partir das contradições introduzidas por ocasião da emergência do capitalismo, em especial a contradição entre as relações de produção e as forças produtivas, foi possível elaborar, após um número significativo de experimentações, um corpo teórico-metodológico crítico e minimamente coerente, qual o materialismo dialético.

Anteriormente, tais preocupações não passavam de um conteúdo indiscernível da experiência humana, embora essa contradição também se assente como um 


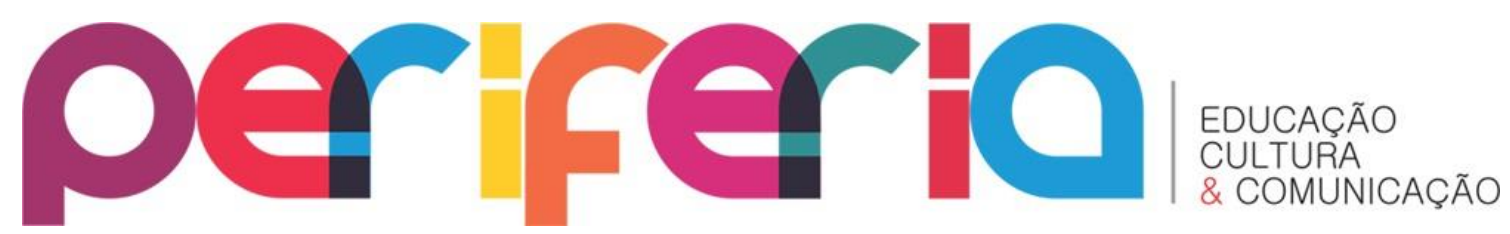

princípio universalista, contribuindo para a reificação de outros tantos conteúdos - em que pese o não reconhecimento de outros grupos sociais, que não a burguesia e 0 proletariado, como sujeitos históricos por sua suposta ausência na reprodução do capital e, portanto, de seu complexo de contradições.

Mas essa constatação não deve ser compreendida de maneira rígida a ponto de considerar que Lukács e Marx não reconheceram a importância de outras classes sociais. O próprio Lukács (2003, p. 111-113) admite, com base nos textos de Rosa Luxemburgo, que a redução da luta de classes às tensões entre capitalistas e proletariados consiste apenas em uma hipótese metodológica utilizada por Marx para lançar luz ao problema, isto é, para lhe dar uma forma objetiva e inteligível. É verdade que, por diversas vezes, Marx aludiu a essa redução atribuindo o status de sujeito histórico àquelas duas classes, mas seria errôneo afirmar que ele não reconheceu o protagonismo de outras classes sociais. Em O 18 de Brumário de Luis Bonaparte, além da burguesia e do proletariado, Marx (2010, p. 35) relaciona uma série de classes entre si em meio a um intricado campo de forças: camponeses, aristocracia, clero, militares, lupemproletariado, latifundiários, classe média, pequena burguesia, além de outras estratificações no interior da própria burguesia, como burguesia comercial, industrial, etc.

Obviamente essa indicação metodológica não esgotou o conjunto dos conteúdos concernentes ao problema da luta de classes, que então permanecera em parte indeterminado, mas parece aflorar em um contexto de modernidade tardia ${ }^{19}$ com a expansão global das contradições do capitalismo. A reestruturação da divisão do trabalho no limiar da sociedade capitalista e suas implicações em termos de exploração da força de trabalho livre (das qualidades criativas e essenciais do homem) têm como consequência mais direta a emergência da classe proletária. Thompson (2010, p. 9) afirma que "a classe operária não surgiu tal como o sol numa hora

\footnotetext{
${ }^{19}$ A expressão modernidade tardia é alusiva a uma proposição de Jameson (2005) em não reiterar uma conotação temporal-linear evocada nas noções de pós-modernidade e pré-modernidade. "Isto quer dizer que tampouco o termo 'pós-moderno' designa um futuro (mas sim, quando usado adequadamente, o nosso próprio presente), ao passo que o 'não-moderno' é inevitavelmente puxado para trás, para um campo de forças no qual tende a ter exclusivamente a conotação de 'pré-moderno' (e de designá-lo, igualmente, em nosso próprio presente global)" (p. 249).
} 


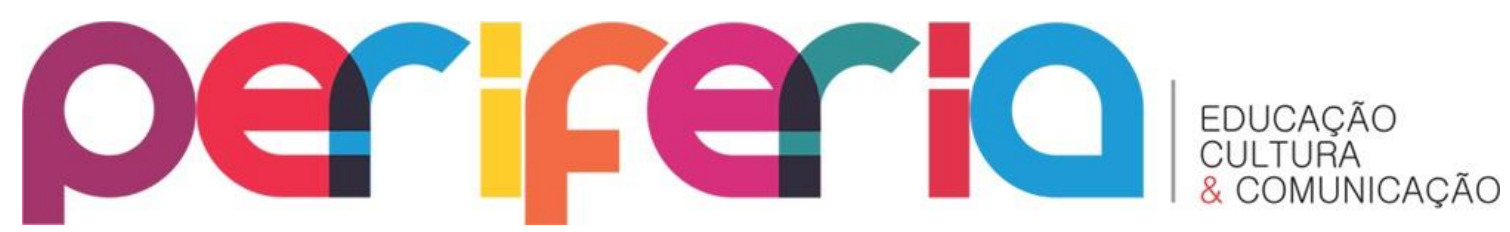

determinada. Ela estava presente ao seu próprio fazer-se". A partir dela, um novo horizonte objetivo vai se desdobrar, após algumas experimentações teóricas (como foi o caso do socialismo utópico, da economia política e da dialética hegeliana), no materialismo dialético. Pode-se inferir, a partir dessa experiência, que a atual incorporação de outros estratos sociais (além do operariado) em uma divisão do trabalho de alcance global responde, em parte, pelo surgimento dos novos (outros) sujeitos históricos. Sujeitos esses cuja implicação no conteúdo objetivo concernente à experiência da luta de classes permanecera, até bem pouco tempo, indeterminado.

Vale destacar que adjetivar esses grupos recalcitrantes como "novos" sujeitos é uma maneira de aludir a um conteúdo até então implícito no horizonte objetivo eurocêntrico da luta de classes. Daí por que ser mais razoável considerá-los como "outros" sujeitos, e não exatamente como "novos" sujeitos.

\footnotetext{
$\mathrm{Ou}$, dito de outra forma, esses sujeitos que muitos chamam novos, embora não o sejam tanto, põem em debate outras questões, outras relações, ele(a)s que tiveram que se forjar em situações assimétricas de poder mas que nem por isso se anularam e, mais do que resistir, R-Existiram, se reinventaram na sua diferença, assim como o europeu é, também, uma invenção na diferença embora na condição de polo dominante no "sistemamundo" (PORTO-GONÇALVES, 2002, p. 220).
}

Ao lado da classe operária, uma série de grupos sociais e de organizações populares se mobiliza contra os mecanismos de exploração e contra os crescentes níveis de desigualdade característicos da sociedade capitalista: movimentos estudantis, movimentos camponeses, grupos eclesiásticos, organizações de luta pelos direitos civis e pelos direitos humanos, associações de moradores, servidores públicos, organizações feministas, ambientalistas, refugiados, migrantes, afrodescendentes, populações indígenas e outras minorias étnico-religiosas, grupos de luta pela instituição de direitos de LGBTs e muitos outros.

A pauta de reivindicações se amplia, incluindo, além de aumento de salários e de melhores condições de trabalho, demarcação de terras e de autonomia territorial, reforma agrária, preservação da tradição cultural, igualdades raciais e de gênero, políticas de ações afirmativas, acesso à moradia, preservação do meio ambiente e espaços da vida cotidiana etc. 


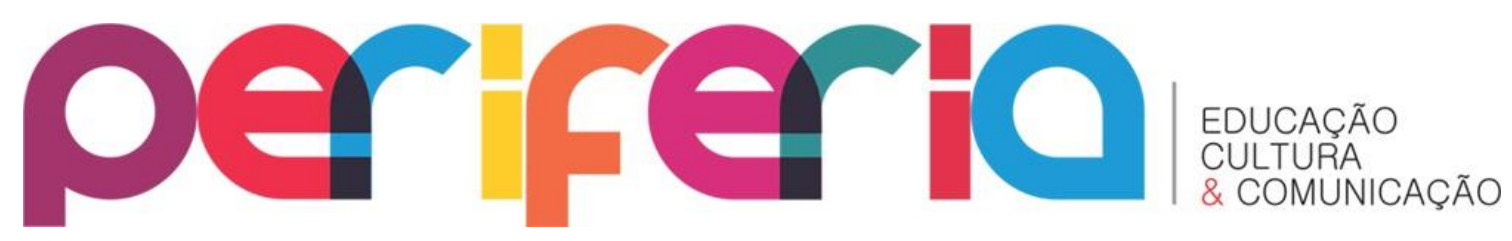

As formas de manifestação variam de greves, paralisações e piquetes a acampamentos, ocupações de terras devolutas e privadas, ocupações de estabelecimentos públicos e privados, bloqueio de estradas, marchas, passeatas, sublevações populares, motins, destruição de transportes coletivos e depredações de estabelecimentos comerciais, encenações artísticas em praças e outros locais públicos e muitas outras formas de exposição dos conflitos.

A maior parte dessas manifestações deriva de reações suscitadas na práxis corporificada dos mais variados grupos sociais implicados na reprodução do capital e, por conseguinte, nos diversos conflitos e levantes decorrentes da apropriação de sua força criativa e transformadora. Concluir que o sujeito se reduz a um único e universal tipo de sujeito, como toda a tradição cartesiana fez, consiste em tolher seu potencial ontológico: sua qualidade corpórea. Subsumi-lo a um sujeito histórico igualmente universal, expresso na imagem do proletariado, como, de sua parte, o marxismo cientificista fez, consiste em suprimir paradoxalmente seu potencial histórico. A própria história tem comprovado que não é esse sujeito histórico privilegiado o único e mais significativo grupo social a despontar como força subversiva contra a ordem capitalista - em que pese, aqui também, a qualidade corpórea do sujeito. É cada vez mais crescente o número de movimentos políticos agrupando contingentes humanos sob bandeiras as mais variadas, muitos dos quais tantas vezes qualificados de sociedades pré-capitalistas e que, por ironia, passaram a engrossar o coro dos oprimidos e dos explorados por conta de sua incorporação como força de trabalho ou reserva (de trabalho, de recursos e de consumo) no sistema capitalista.

A integração de um sem-número de grupos sociais com seus modos de existência domésticos e comunitários à cadeia mercantil global, na maior parte dos casos incorporados de maneira precária e não necessariamente devotados exclusivamente à reprodução do capitalismo, autoriza-nos a considerá-los sujeitos históricos reais. Não somente porque, uma vez integrados como força de trabalho, passariam a mobilizar esforços no sentido de combater a exploração e as injustiças 


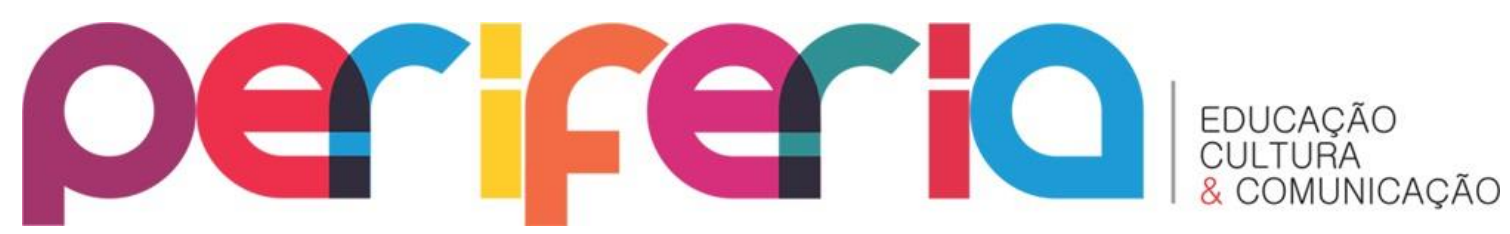

características do sistema capitalista, mas também porque passariam a compartilhar, de maneira nuançada, o mesmo ser social aventado pela sociedade capitalista.

Nosso argumento, todavia, não consiste em reclamar o reconhecimento desses grupos recalcitrantes como classes, mas sim em depreender seu potencial de transformação social. Não basta, portanto, compreendê-los implicados ao modo de produção capitalista para, um tanto quanto arbitrariamente, reconhecê-los como sujeitos históricos. Uma vez constatada essa integração, é preciso identificá-los como agentes criativos e transformadores das relações de subordinação a que estariam submetidos.

A capacidade de transformação dos mais variados modos de existência de regime comunitário, caso reconheçamos esses grupos como legítimos sujeitos históricos, deve-se, portanto, menos à eventual condição de classe dos indivíduos que os compõem (ou por estarem diretamente subordinados à exploração capitalista) do que por sua constatação enquanto sujeitos corporificados, cuja matriz sensível está implicada na mesma matriz sensível e autopoiética da materialidade histórico-social.

Mesmo que esses grupos sociais não sejam classes no sentido rigoroso do termo, não expressando, por meio de suas práticas, um sentimento revolucionário de transformação social quando confrontadas com determinadas condições deletérias de existência impostas pelas forças hegemônicas da sociedade, não deixam, por isso mesmo, de constar como sujeitos de seu próprio devenir histórico. Sob esse aspecto, poder-se-ia dizer que estão a meio-caminho de sua emancipação ${ }^{20}$.

Ainda que taxados de sociedades pré-capitalistas, grupos étnicos, estratos semiproletarizados ou seja lá qual for a forma que compareça ao discurso abjudicador da consciência, esses grupos e seus gêneros de vida refratários, por um lado, integramse, por meio da reprodução desigual do capitalismo, no circuito global da produção, da circulação, da troca e do consumo de mercadorias; por outro, introduzem novas expressões de luta social e política.

\footnotetext{
${ }^{20}$ Expressão esta tomada muito mais como expediente retórico do que em sentido literal, já que em meio à complexidade do mundo contemporâneo qualquer tipo de emancipação ou autonomia será sempre relativa.
} 


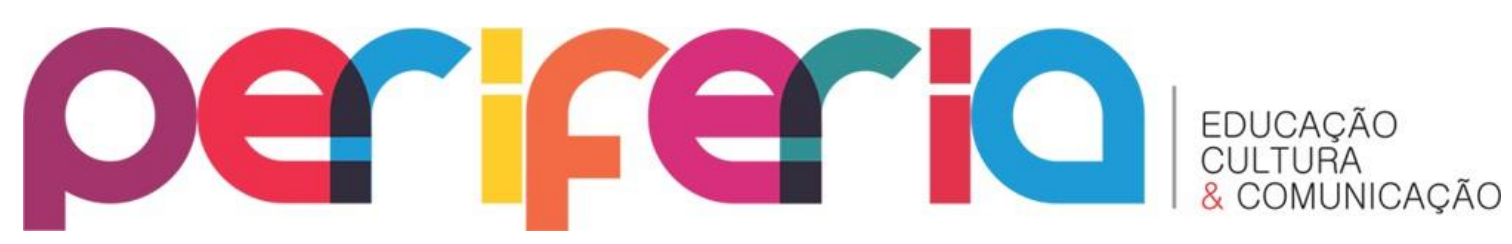

Tudo parece indicar que está ocorrendo no mundo periférico aos grandes centros capitalistas (e mesmo no seio deles) um despertar político das massas trabalhadoras que não se restringem à forma objetiva clássica da classe operária. Wallerstein (2001, p. 79) avalia que, a partir de 1950, os movimentos antissistêmicos passaram a abranger "mais áreas periféricas, mais mulheres, mais grupos 'minoritários' (das mais diferentes definições) e uma parcela maior do setor menos qualificado e menos remunerado da força de trabalho".

Essa emergência é, de certo modo, fruto do acesso, por parte desses agentes subalternizados, a certos conteúdos indeterminados da própria experiência de reprodução da sociedade, cujas formas objetivas vêm à tona com a globalização das contradições da reprodução da sociedade capitalista. A capacidade de construção do "novo" por parte desses grupos populares confirma-os como sujeitos históricos efetivos.

\section{REFERÊNCIAS}

BENSAÏD, Daniel. Um olhar sobre a história e sobre a luta de classes. In: BORON, A.; AMADEO, J.; GONZÁLEZ, S. (orgs.). A teoria marxista hoje: problemas e perspectivas. Buenos Aires: CLACSO, 2006.

BUEY, Francisco Fernández. Marx (sem ismos). Rio de Janeiro: Editora UFRJ, 2004. ENGELS, Friedrich. Prefácio à 3a edição [de 1885]. In: MARX, Karl. O 18 de Brumário de Luís Bonaparte. São Paulo: Boitempo, 2010.

FURET, François. Pensando a Revolução Francesa. Rio de Janeiro: Paz e Terra, 1989.

HARVEY, David. O enigma do capital e as crises do capitalismo. São Paulo: Boitempo, 2011.

HOBSBAWM, Eric J. Mundos do trabalho: novos estudos sobre história operária. Rio de Janeiro: Paz e Terra, 2000.

HOUTART, François. Os movimentos sociais e a construção de um novo sujeito histórico. In: BORON, A.; AMADEO, J.; GONZÁLEZ, S. (orgs.). A teoria marxista hoje: problemas e perspectivas. Buenos Aires: CLACSO, 2006.

JAMESON, Fredric. Modernidade singular: ensaio sobre a ontologia do presente. Rio de Janeiro: Civilização Brasileira, 2005.

LEFEBVRE, Georges. O surgimento da Revolução Francesa. Rio de Janeiro: Paz e Terra, 1989.

LEFEBVRE, Henri. La presencia y la ausencia: contribución a la teoria de las representaciones. México: Fondo de Cultura Económica, 2006. 


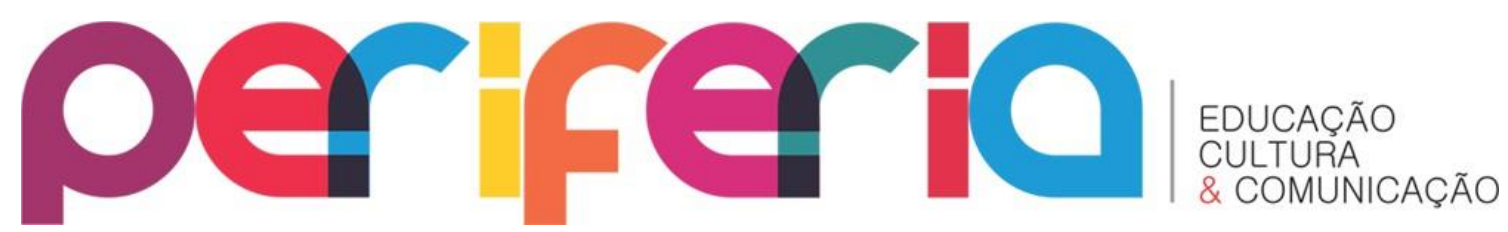

LOJKINE, Jean. O Estado capitalista e a questão urbana. São Paulo: Martins Fontes, 1997.

LUKÁCS, György. História e consciência de classe: estudos sobre a dialética marxista. São Paulo: Martins Fontes, 2003.

MATTOS, Marcelo Badaró. Classes sociais e luta de classes: atualidade dos conceitos. Em Pauta: teoria social \& realidade contemporânea. Rio de Janeiro, UERJ, no 20, p. 3355, 2007.

MARX, Karl. O 18 de Brumário de Luís Bonaparte. São Paulo: Boitempo, 2010.

; ENGELS, Friedrich. Manifesto comunista. São Paulo: Boitempo, 2005.

PORTO-GONÇALVES, Carlos Walter. Da Geografia às Geo-grafias: um mundo em busca de novas territorialidades. In: SADER, Emir; CECEÑA, Ana Esther (orgs.). La guerra infinita: hegemonia y terror mundial. Buenos Aires: CLACSO, 2002.

QUIJANO, Aníbal. Colonialidade do poder e classificação social. In: SANTOS, Boaventura de Sousa; MENEZES, Maria Paula (orgs.). Epistemologias do Sul. São Paulo: Cortez, 2010.

THOMPSON, Edward Palmer. A miséria da teoria ou um planetário de erros: uma crítica ao pensamento de Althusser. Rio de Janeiro: Zahar, 1981.

Costumes em comum: estudos sobre a cultura popular tradicional. São Paulo:

Companhia das Letras, 1998.

A formação da classe operária inglesa I: a árvore da liberdade. Rio de Janeiro: Paz e Terra, 2010.

WALLERSTEIN, Immanuel. Capitalismo Histórico e Civilização Capitalista. Rio de Janeiro: Contraponto, 2001. 